\title{
Phytoplankton diversity in the middle Rio Doce lake system of southeastern Brazil
}

Cristiane Freitas de Azevedo Barros ${ }^{1,3}$, Aline Morena Menezes dos Santos ${ }^{2}$ and Francisco Antônio Rodrigues Barbosa ${ }^{2}$

Submitted: 22 June, 2011. Accepted: 15 January, 2013

\begin{abstract}
This study presents results of the inventory of algal flora conducted between August 2007 and May 2008 in 18 lakes of the middle Rio Doce lake system, most of which is in the state of Minas Gerais, Brazil. We recorded 481 taxa, increasing the known total phytoplankton diversity of the region (gamma diversity) by $80 \%$. The following classes were represented: Zygnematophyceae (171 taxa), Cyanobacteria (101), Chlorophyceae (71), Bacillariophyceae (42), Euglenophyceae (43), Trebouxiophyceae (24), Dinophyceae (8), Xanthophyceae (8), Chrysophyceae (6), Cryptophyceae (6) and Oedogoniophyceae (1). We identified 221 taxa that were rare (restricted to one or two lakes), and 101 that were considered representative (present in at least nine lakes). Botryococcus braunii, Elakatothrix genevensis, Planktolyngbya limnetica, Peridinium pusillum, Trachelomonas volvocina, Cosmarium contractum, Staurastrum forficulatum, Staurastrum leptocladum, Staurastrum rotula, and Staurodesmus dejectus were present in all lakes. Richness varied from 95 taxa (in Lake Gambazinho) to 168 taxa (in Lake Palmeirinha). Jaccard indices were low, and the highest similarities between lakes were 53\% (Ferrugem/Ferruginha), 47\% (Central/Almécega) and 46\% (Águas Claras/Palmeirinha), demonstrating high environmental and biotic dissimilarities between lakes. Geographic distance was not significantly associated with floristic similarity, suggesting that local factors are more important than are regional ones in shaping the phytoplankton composition of lakes.
\end{abstract}

Key words: algal flora, inventory, tropical lakes

\section{Introduction}

Species richness is considered one of the simplest measures to express and quantify biological complexity in a given region (Nabout et al. 2007). In aquatic environments, species richness is influenced by several factors, including water temperature, mixing patterns of the water column, light, nutrient availability, and herbivory (Reynolds, 1987). Therefore, knowledge of richness patterns is essential to proposals for monitoring strategies and for biodiversity conservation activities (Downing \& Leibold 2002; Declerck et al. 2005; Nogueira et al. 2008).

Diversity can be assessed on different scales. Local, or alpha, diversity is given by the total number of species in each habitat. Regional, or gamma, diversity is the total number of species observed in a range of habitats (Magurran 2004). The term beta diversity was introduced by Whittaker in the 1960s. At first the term was used in order to describe changes in species composition along gradients of altitude and humidity through differences in rates of gain and loss of species. However, beta diversity is now defined as the taxonomic difference between samples, whether occurring along an environmental gradient or not (Veech et al. 2002).

The middle Rio Doce lake system is a large freshwater system in southeastern Brazil, formed as a result of a mass of sediments (from the original drainages of Rio Doce and its tributaries) that acted as a natural dam, giving rise to a dense network of lakes (Pflug 1969 cited in de Meis \& Tundisi 1997). The biological and ecological importance of the system was recently demonstrated by its recognition as an international Ramsar site, making it the 11th site in Brazil to be added to the Ramsar list of wetlands of international importance (Ramsar 2010).

Limnological research in the middle Rio Doce lake system was initiated in the 1970s (Tundisi \& Saijo 1997). Since then, various aspects have been investigated (Barbosa \& Tundisi 1980; Henry \& Barbosa 1989; Rocha et al. 1989; Tundisi \& Saijo 1997), increasing knowledge of the geological, morphological, physical, chemical, and biological characteristics of the lakes. However, specific studies on phytoplankton were mainly focused on Lake Dom Helvécio and Lake Carioca (Hino et al. 1986; Taniguchi et al. 2003;

\footnotetext{
${ }^{1}$ Universidade do Estado de Minas Gerais, Frutal, MG, Brazil

${ }^{2}$ Universidade Federal de Minas Gerais, Instituto de Ciências Biológicas, Laboratório de Limnologia, Belo Horizonte, MG, Brazil

${ }^{3}$ Author for correspondence crisfabarros@gmail.com
} 
Barros et al. 2006; Souza et al. 2008). However, a recent survey evaluated plankton diversity in a larger number of lakes (Maia-Barbosa et al. 2006). Therefore, there is still little information on phytoplankton diversity in this lake system, as shown by Barbosa et al. (1994). The present study aims to contribute to the knowledge of phytoplankton diversity of this lake complex by presenting the results of an inventory of the algal flora in 18 lakes.

\section{Material and methods}

\section{Study area}

The Rio Doce basin is located at in southeastern Brazil, between the state of Minas Gerais ( $86 \%$ of the total area) and the state of Espírito Santo (14\% of the total area), encompassing $83,400 \mathrm{~km}^{2}$ (Marques \& Barbosa, 2002). Two lake systems compose this basin: one, at the middle course, comprising ca. 250 lakes, distinct in their trophic status (Maillard et al. 2011), and another, at the lower course, comprising ca. 70 lakes (Cavati \& Fernandes 2008). Approximately 50 lakes in the middle course are protected within Rio Doce State Park, a conservation unit created in 1939 and representing the largest contiguous remnant of the Atlantic Forest in Minas Gerais $\left(359.76 \mathrm{~km}^{2}\right)$. Lakes located in the surrounding area are affected mainly by hardwood (Eucalyptus spp.) plantations and pastureland, among several municipalities.

For the purposes of this study, 18 lakes were selected: eight located inside the Rio Doce State Park limits and ten in the surrounding areas (Fig. 1; Tab. 1). In selecting the lakes, we took into account their greatest physiographic differences and their accessibility, mainly during the rainy (summer) season. The climate of the region is classified as tropical semi-humid with 4-5 months of dry weather, exhibiting mesothermal characteristics (Nimer, 1989) with temperatures of approximately $25^{\circ} \mathrm{C}$. According to Tundisi (1997), the monthly precipitation is highest in December $(350 \mathrm{~mm})$ and lowest in July and August $(10 \mathrm{~mm})$.

\section{Samplings}

Field work was conducted quarterly, in August 2007, November 2007, February 2008, and May 2008. Samples were collected from a fixed point in the limnetic region of each lake. Samplings were authorized by the Minas Gerais State Forestry Institute (permit no. 005/07). Water transparency was estimated in situ by Secchi disk measurements (Cole 1983). Samples were collected for total phosphorus quantification (Mackereth et al. 1978).

Samples for qualitative analysis of phytoplankton were collected by successive vertical and horizontal throws with a 20- $\mu \mathrm{m}$ mesh plankton net, then fixed with $4 \%$ formaldehyde solution. For each qualitative sample (four samples/lake), eight slides were analyzed, for a total of 32 slides per lake. Organisms were identified under light microscopy down to

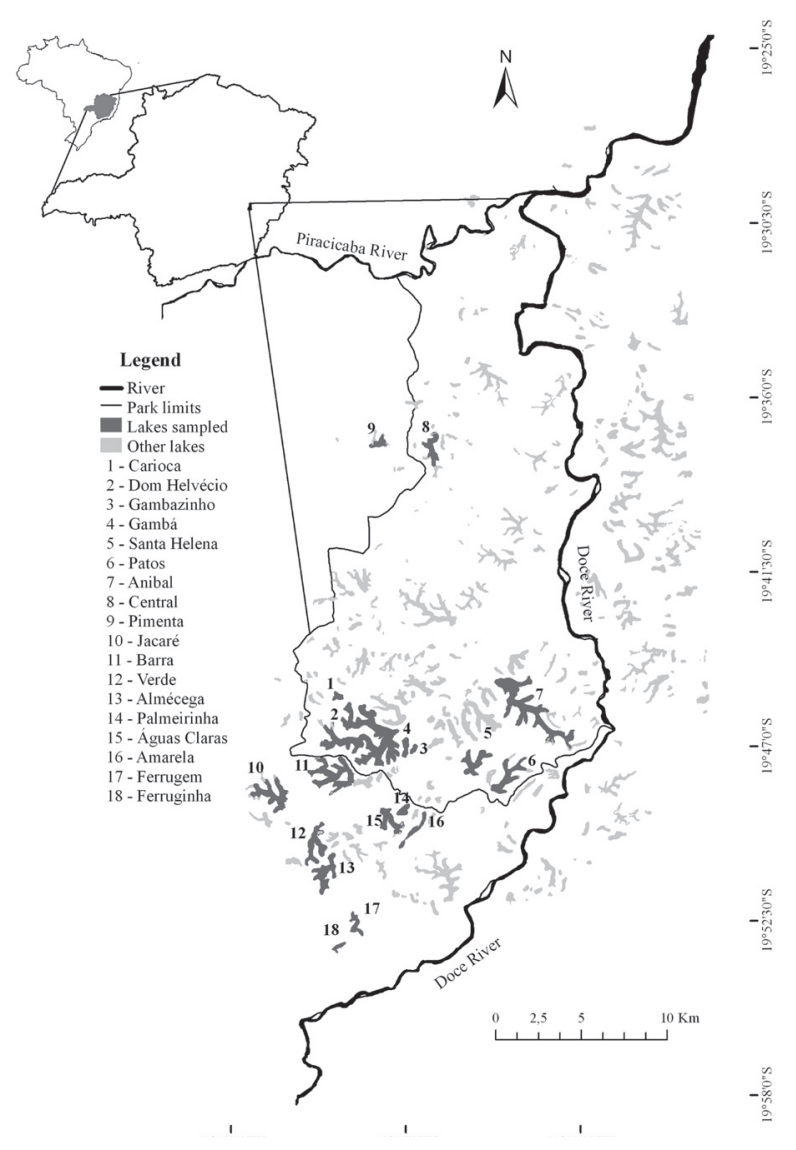

Figure 1. Middle Rio Doce lake system, showing the outline of Rio Doce State Park, sampled lakes (1 to 18), and limnetic fixed points of sampling (+). Digital base (shapefiles) provided by the Minas Gerais State Forestry Institute.

the lowest possible taxonomic level using a specific bibliography: Föster (1969; 1974), Prescott et al. (1975; 1977; 1981; 1982), Komárek \& Fott (1983), Sant’Anna (1984), Komárek \& Anagnostidis (1989; 1999), Menezes et al. (1995), and Bicudo \& Menezes (2006). Samples for quantitative analyses were collected with van Dorn bottles at three depths (100\%, $10 \%$, and $1 \%$ of incident light, as defined with Secchi disk measurements) and fixed with Lugol's solution. Quantitative analysis followed the method described by Utermöhl (1958).

\section{Data analysis}

For each lake, species richness was assessed on the basis of the number of taxa identified, considering the qualitative and quantitative data. Species richness for the sampled region (gamma diversity) was estimated with the first-order jackknife estimator (Nabout et al. 2007), using Stimate S software (Colwell 2006). Beta diversity was estimated by the difference between gamma diversity (total species recorded for the set of lakes) and average alpha diversity (mean species richness per lake), as suggested by Crist et al. (2003):

$$
\beta=\gamma-\text { mean } \alpha
$$


Table 1. Geographic coordinates, depth, margin development index, area, transparency, and total phosphorous concentration of 18 lakes sampled in the middle Rio Doce lake system, between August 2007 and May 2008.

\begin{tabular}{|c|c|c|c|c|c|c|c|}
\hline Location & Lake (abbreviation) & Geographic coordinates & $\begin{array}{l}\text { Depth } \\
(\mathrm{m})\end{array}$ & DL & $\begin{array}{l}\text { Area } \\
\left(\mathrm{km}^{2}\right)\end{array}$ & $\begin{array}{l}\text { Secchi } \\
(\mathrm{m})\end{array}$ & $\begin{array}{c}\text { Total phosphorous } \\
(\mu \mathrm{g} / \mathrm{L})\end{array}$ \\
\hline \multirow{8}{*}{ State Park } & Aníbal (AN) & $19^{\circ} 06^{\prime} 47.1^{\prime \prime} \mathrm{S} ; 42^{\circ} 29^{\prime} 54.5^{\prime \prime} \mathrm{W}$ & 6.0 & 4.29 & 2.79 & $2.44 \pm 0.13$ & $30.12 \pm 18.74$ \\
\hline & Carioca (CA) & $19^{\circ} 45^{\prime} 26.0^{\prime \prime} \mathrm{S} ; 42^{\circ} 37^{\prime} 06.2^{\prime \prime} \mathrm{W}$ & 10.0 & 1.28 & 0.13 & $1.70 \pm 0.32$ & $17.31 \pm 6.75$ \\
\hline & Central (CE) & $19^{\circ} 37^{\prime} 39.0^{\prime \prime} \mathrm{S} ; 42^{\circ} 34^{\prime} 12.5^{\prime \prime} \mathrm{W}$ & 5.0 & 2.03 & 0.44 & $0.81 \pm 0.18$ & $30.44 \pm 10.72$ \\
\hline & Dom Helvécio (DH) & $19^{\circ} 46^{\prime} 55.7^{\prime \prime} \mathrm{S} ; 42^{\circ} 35^{\prime} 28.9^{\prime \prime} \mathrm{W}$ & 28.0 & 4.93 & 5.27 & $2.48 \pm 0.55$ & $20.13 \pm 8.86$ \\
\hline & Gambá (GA) & $19^{\circ} 47^{\prime} 15.1^{\prime \prime} \mathrm{S} ; 42^{\circ} 35^{\prime} 01.0^{\prime \prime} \mathrm{W}$ & 12.0 & 1.13 & 0.22 & $3.23 \pm 0.67$ & $13.27 \pm 4.46$ \\
\hline & Gambazinho (GN) & $19^{\circ} 47^{\prime} 07.7^{\prime \prime} \mathrm{S} ; 42^{\circ} 34^{\prime} 45.5^{\prime \prime} \mathrm{W}$ & 10.0 & 2.9 & 0.09 & $1.78 \pm 0.22$ & $23.29 \pm 8.51$ \\
\hline & Patos (PT) & $19^{\circ} 48^{\prime} 19.9^{\prime \prime} \mathrm{S} ; 42^{\circ} 32^{\prime} 12.7^{\prime \prime} \mathrm{W}$ & 8.0 & 2.01 & 1.09 & $2.47 \pm 0.82$ & $27.33 \pm 6.69$ \\
\hline & Santa Helena (SH) & $19^{\circ} 47^{\prime} 48.8^{\prime \prime} \mathrm{S} ; 42^{\circ} 33^{\prime} 04.7^{\prime \prime} \mathrm{W}$ & 10.5 & 2.42 & 0.86 & $2.26 \pm 0.44$ & $26.77 \pm 11.81$ \\
\hline \multirow{10}{*}{ Surroundings } & Águas Claras (AC) & $19^{\circ} 49^{\prime} 06.9^{\prime \prime} \mathrm{S} ; 42^{\circ} 35^{\prime} 42.5^{\prime \prime} \mathrm{W}$ & 9.5 & 2.24 & 0.62 & $3.28 \pm 1.35$ & $16.16 \pm 7.35$ \\
\hline & Almécega (AL) & $19^{\circ} 51^{\prime} 25.4^{\prime \prime} \mathrm{S} ; 42^{\circ} 37^{\prime} 31.9^{\prime \prime} \mathrm{W}$ & 7.0 & 2.44 & 1.3 & $2.81 \pm 0.55$ & $19.21 \pm 14.10$ \\
\hline & Amarela (AM) & $19^{\circ} 49^{\prime} 23.1^{\prime \prime} \mathrm{S} ; 42^{\circ} 34^{\prime} 28.7^{\prime \prime} \mathrm{W}$ & 2.5 & 1.82 & 0.27 & $0.86 \pm 0.11$ & $75.46 \pm 64.80$ \\
\hline & Barra (BA) & $19^{\circ} 48^{\prime} 11.1^{\prime \prime} \mathrm{S} ; 42^{\circ} 37^{\prime} 43.6^{\prime \prime} \mathrm{W}$ & 7.0 & 3.45 & 1.94 & $2.45 \pm 0.76$ & $47.91 \pm 32.13$ \\
\hline & Ferrugem (FE) & $19^{\circ} 52^{\prime} 39.0^{\prime \prime} \mathrm{S} ; 42^{\circ} 36^{\prime} 34.3^{\prime \prime} \mathrm{W}$ & 3.5 & 1.61 & 0.42 & $0.93 \pm 0.25$ & $49.96 \pm 21.92$ \\
\hline & Ferruginha (FN) & $19^{\circ} 53^{\prime} 17.5^{\prime \prime} \mathrm{S} ; 42^{\circ} 36^{\prime} 59.4^{\prime \prime} \mathrm{W}$ & 4.0 & 1.4 & 0.12 & $1.03 \pm 0.05$ & $32.99 \pm 12.53$ \\
\hline & Jacaré (JA) & $19^{\circ} 48^{\prime} 37.8^{\prime \prime} \mathrm{S} ; 42^{\circ} 38^{\prime} 57.0^{\prime \prime} \mathrm{W}$ & 8.5 & 1.28 & 1.22 & $1.95 \pm 0.17$ & $42.49 \pm 18.30$ \\
\hline & Palmeirinha (PA) & $19^{\circ} 49^{\prime} 41.8^{\prime \prime} \mathrm{S} ; 42^{\circ} 36^{\prime} 25.4^{\prime \prime} \mathrm{W}$ & 6.0 & 2.83 & 0.23 & $2.26 \pm 0.60$ & $28.36 \pm 17.93$ \\
\hline & Pimenta (PI) & $19^{\circ} 37^{\prime} 27.4^{\prime \prime} \mathrm{S} ; 42^{\circ} 35^{\prime} 44.3^{\prime \prime} \mathrm{W}$ & 3.5 & 1.63 & 1.24 & $1.13 \pm 0.25$ & $37.78 \pm 22.38$ \\
\hline & Verde (VE) & $19^{\circ} 49^{\prime} 55.2^{\prime \prime S} ; 42^{\circ} 37^{\prime} 54.1^{\prime \prime} \mathrm{W}$ & 19.0 & 2.29 & 0.83 & $2.19 \pm 0.58$ & $14.38 \pm 4.24$ \\
\hline
\end{tabular}

DL - development index.

where $\beta$ is beta diversity, $\gamma$ is gamma diversity, and $\alpha$ is alpha diversity.

Differences in relation to water transparency and total phosphorus levels were determined using ANOVA. Spearman's correlation coefficient was used in order to test for relationships between the morphometric features (area, depth, and margin development index) and physico-chemical variables. Hierarchical cluster analysis using Jaccard distance and Ward's method (Ward 1963) were performed in order to assess similarity between lakes in terms of the phytoplankton species composition. These statistical analyses were conducted using Past 1.90 software (Hammer et al. 2001).

\section{Results and discussion}

Morphometric features, such as depth, margin development index, and area, varied among lakes (Table 1). Secchi depth and total phosphorus concentrations also differed among lakes $(\mathrm{F}=996.888 ; \mathrm{p}=0.000$ and $\mathrm{F}=730.533 ; \mathrm{p}=0.000$, respectively) and correlated with depth $(\mathrm{p}<0.05 ; \mathrm{r}=0.630$ for Secchi disk measurements and $\mathrm{r}=0.596$ for total phosphorus concentrations). Lakes that were shallower ( $<5 \mathrm{~m}$ : Pimenta, Central, Amarela, Ferrugem, and Ferruginha) showed lower
Secchi disappearance depths $(>1.2 \mathrm{~m})$ and higher levels of total phosphorus ( $>30 \mu \mathrm{g} / \mathrm{L}$; especially Lakes Amarela and Ferrugem, in which total phosphorus was $>50 \mu \mathrm{g} / \mathrm{L}$ ), than did the lakes that were deeper (>7 m: Dom Helvécio, Águas Claras, Almécega, Gambá, and Verde), which showed greater water transparency (down to $2.2 \mathrm{~m}$ ) and lower values of the trophy indicator (below $21 \mu \mathrm{g} / \mathrm{L}$ of phosphorus).

Richness extrapolation indices, such as the jackknife, although not usually used for phytoplankton (Nabout et al. 2007; Nogueira et al. 2008), can be important tools to assess the representativeness of the sampling effort. In the present study, a total of 481 taxa were recorded (Fig. 2), corresponding to $77 \%$ of the expected richness, estimated using first-order jackknife (jackknife $1=624$ ). The relationship between the observed and estimated values for richness indicated that our methods were appropriate for a diversity survey. In addition, the known phytoplankton diversity in the middle Rio Doce lake system was high in comparison with the 267 species reported for seven lakes in the system by Maia-Barbosa et al. (2006). Gamma diversity increased by $80 \%$ with the expansion of the number of studied environments, reinforcing the observed environmental and biotic heterogeneity.

Eleven classes were identified: Zygnematophyceae (171 taxa), Cyanobacteria (101), Chlorophyceae (71), Bacillario- 


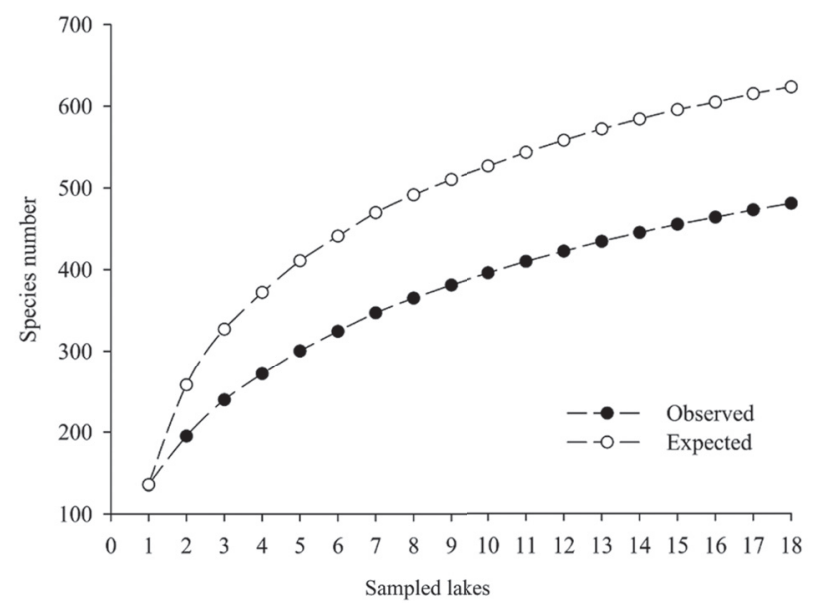

Figure 2. Species accumulation curve of 18 lakes sampled in the middle Rio Doce lake system, between August 2007 and May 2008.

phyceae (42), Euglenophyceae (43), Trebouxiophyceae (24), Dinophyceae (8), Xanthophyceae (8), Chrysophyceae (6), Cryptophyceae (6) and Oedogoniophyceae (1); Appendix 1. The predominance of desmids, especially those of the genera Cosmarium, Staurastrum and Staurodesmus, in the middle Rio Doce lakes was previously reported by Reynolds (1997), who attributed the dominance of this group to oligotrophic conditions and good preservation of the lakes. It has also been suggested that the thermal stratification pattern known as atelomixis (characterized by unusual, irregular circulation periods of short duration) is a key factor for desmid prevalence (Barbosa \& Padisák 2002; Souza et al. 2008), because it allows these species, which have relatively high specific density (Padisák et al. 2003), to remain within the upper layers of the water column.

Of the 481 taxa identified, 221 were rare, occurring exclusively in one or two lakes, and 101 exhibited high frequency, occurring in at least nine lakes (Tab. 2). In addition, 10 species were common to all lakes: Botryococcus braunii Kützing, Elakatothrix genevensis (Reverdin) Hindák, Planktolyngbya limnetica (Lemmerman) Komárkova-Legnerová and Cronberg, Peridinium pusillum (Pénard) Lemmerman, Trachelomonas volvocina Ehrenberg, Cosmarium contractum Kirchner, Staurastrum forficulatum Lundell, Staurastrum leptocladum Nordstedt, Staurastrum rotula Nordstedt, and Staurodesmus dejectus (Brébisson) Teiling.

Phytoplankton richness ranged from 95 taxa (Lake Gambazinho) to 168 taxa (Lake Palmeirinha). In general, the most representative groups for each lake were the same observed for the data set: Zygnematophyceae $>$ Chlorophyceae > Cyanobacteria; exceptions occurred for Lake Amarela, where the number of Euglenophyceae species (25) exceeded that of Cyanobacteria species (15), and for Lake Gambazinho, which had more Bacillariophyceae species (22) than Cyanobacteria species (12) (Fig. 3). The predominance of Euglenophyceae in Lake Amarela, previously reported by Reynolds (1997), is associated with its late successional stage, shallowness, and broad macrophyte coverage of the surface area, mainly with Nymphaea sp., Utricularia sp., and Eleocharis sp.

Table 2. List of the most common species in the 18 lakes sampled in the middle Rio Doce lake system between August 2007 and May 2008

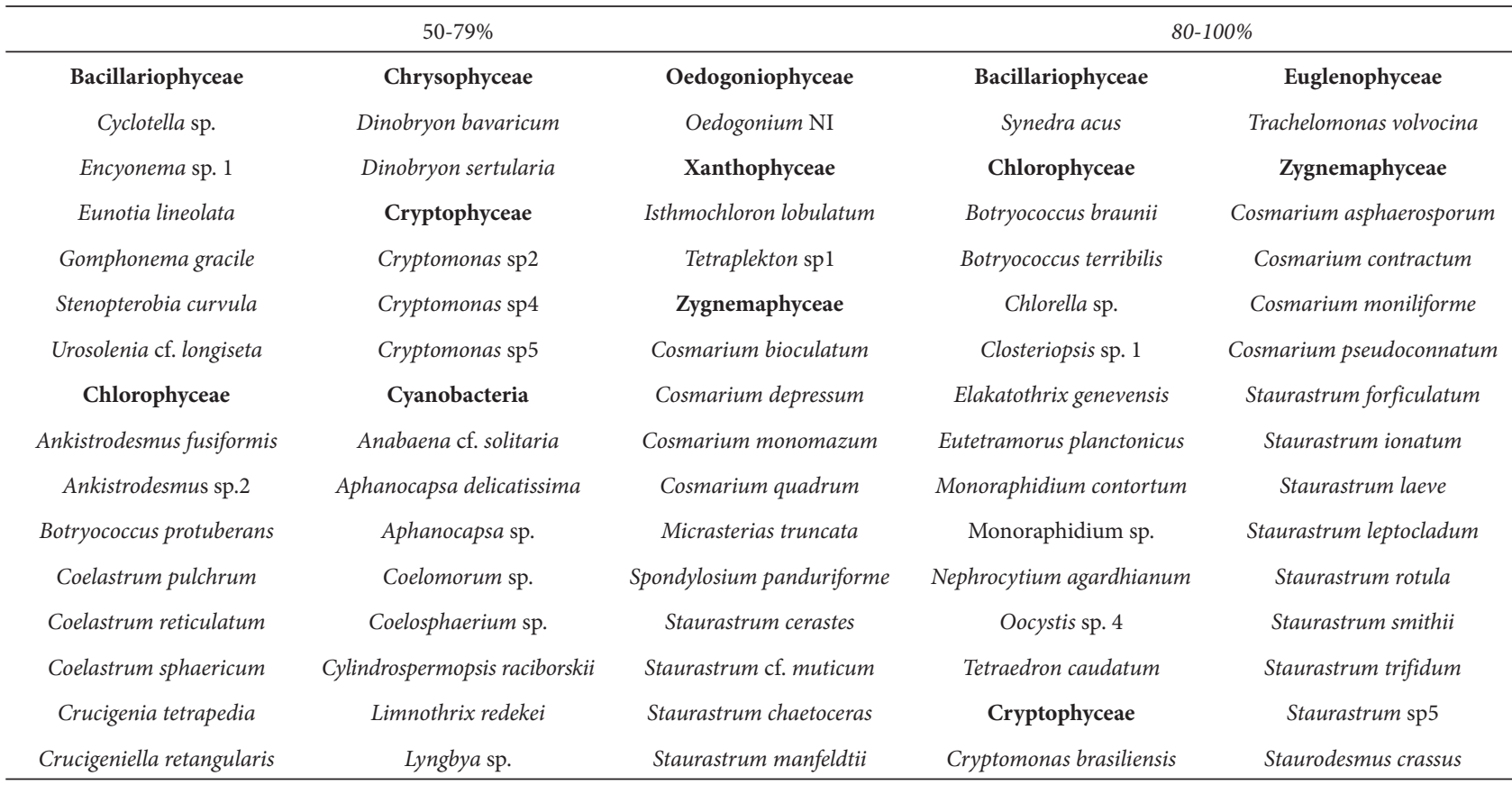


Table 2. Continuation.

\begin{tabular}{cccc}
\hline & $50-79 \%$ & & $80-100 \%$ \\
\hline Desmodesmus armatus & Merismopedia tenuissima & Staurastrum setigerum & Cyanobacteria \\
var. bicaudatus & Microcystis aeruginosa & Staurastrum tetracerum & Aphanocapsa elachista \\
Dictyosphaerium pulchellum & Oscillatoria sp 1 & Staurastrum sp6 & Chroococcus minutus \\
Keratococcus sp. & Planktolyngbya contorta & Staurodesmus convergens & Planktolyngbya limnetica \\
Kirchneriella lunaris & Pseudanabaena limnetica & Staurodesmus cuspidatus & Pseudanabaena galeata \\
Oocystis lacustris & Dinophyceae & Staurodesmus subulatus & Deilingia granulata \\
Oocystis sp. 3 & Peridinium cf. africanum & & Gymnodynium sp. \\
Scenedesmus bijugus & Euglenophyceae & & Peridinium pusillum \\
Scenedesmus quadricauda & Phacus longicauda & & Peridinium baliense \\
Tetraedron minimum & Phacus raciborskii & & \\
\hline
\end{tabular}

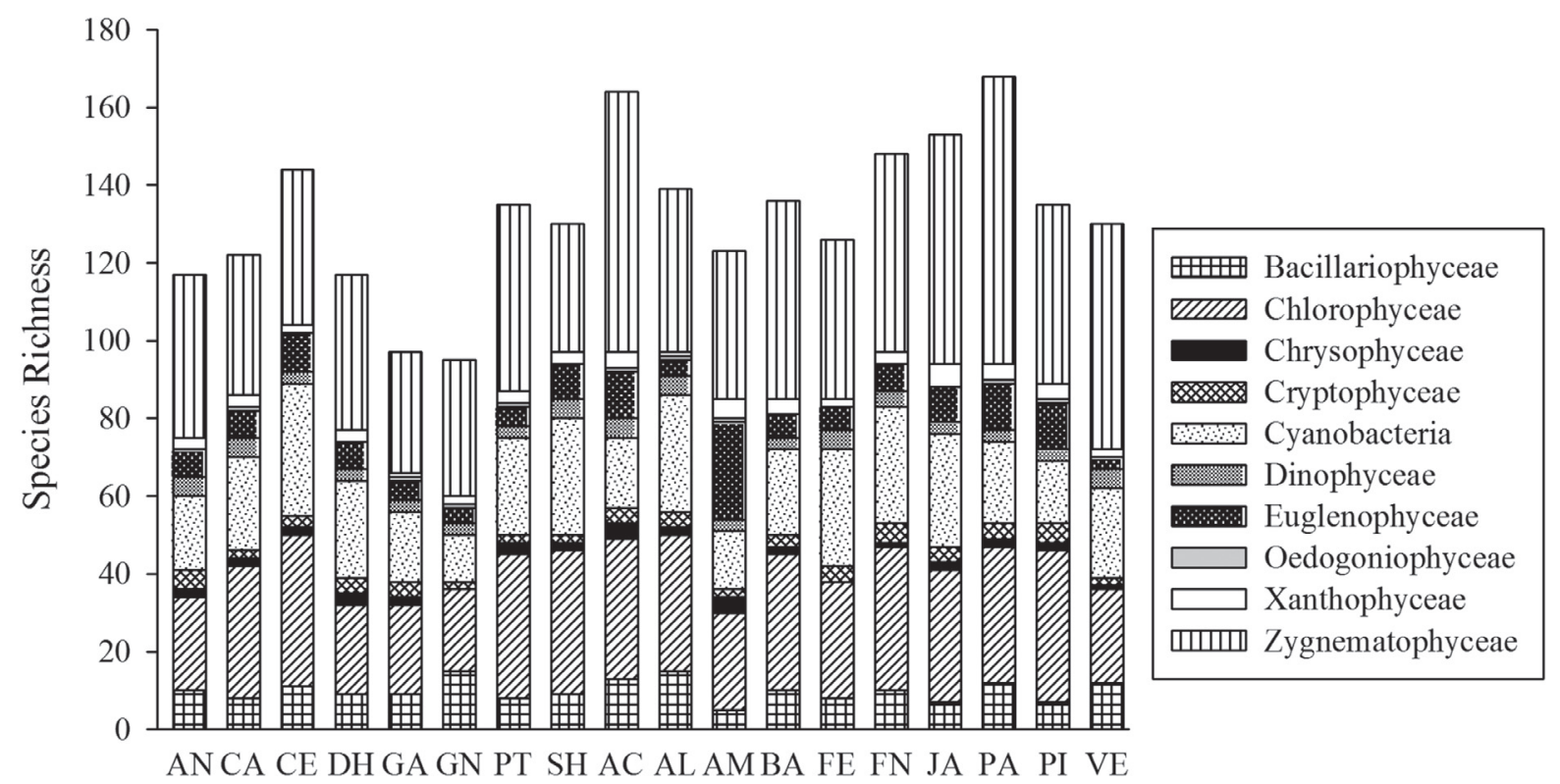

Figure 3. Species richness and contribution of each taxonomic class of 18 lakes sampled in the middle Rio Doce lake system, between August 2007 and May 2008: Águas Claras (AC), Almécega (AL), Amarela (AM), Aníbal (AN), Barra (BA), Carioca (CA), Central (CE), Dom Helvécio (DH), Ferrugem (FE), Ferruginha (FN), Gambá (GA), Gambazinho (GN), Jacaré (JA), Palmeirinha (PA), Patos (PT), Pimenta (PI), Santa Helena (SH), and Verde (VE).

Lake Amarela showed the highest number of exclusive taxa (26), followed by Lakes Gambazinho (15), Jacaré (13), and Palmeirinha (13). The lowest numbers of exclusive species were observed in Lakes Ferrugem (1), Carioca (2), and Ferruginha (2).

The fact that the incidence of exclusive species was highest in Lakes Amarela and Gambazinho indicates the great importance of the shoreline regions, given that, in the case of Lake Gambazinho, the main representative species were diatoms of the order Pennales ( 6 taxa) and large desmids (5 taxa), the latter also prevailing in Lake Amarela (12 taxa), together with
Euglenophyceae ( 7 taxa). Those two lakes are quite distinct from the other lakes of the region and from those presented here. In Lake Amarela, high amounts of organic matter reflect its advanced state of eutrophication, as evidenced by the total phosphorous and transparency values. Lake Gambazinho has a polymictic pattern of thermal stratification, in contrast to the more common warm-monomictic pattern of thermal stratification observed in the majority of the middle Rio Doce lakes. Such characteristics seem to have been responsible for the higher numbers of typically periphytic species in the samples collected from these lakes. 
We obtained low Jaccard indices. The highest similarities were 53\% for Lake Ferrugem versus Lake Ferruginha, followed by $47 \%$ for Lake Central versus Lake Almécega, and $46 \%$ for Lake Águas Claras versus Lake Palmeirinha. Lake Amarela showed the lowest similarity with the other lakes, ranging from $14 \%$ to $25 \%$.

On the basis of phytoplankton species composition, we identified five clusters of lakes (Fig. 4): cluster 1-Lakes Aníbal, Carioca, Pimenta, Dom Helvécio, and Santa Helena; cluster 2-Lakes Central, Almécega, Ferrugem, and Ferruginha; cluster 3-Lakes Águas Claras, Palmeirinha, Patos, Barra, Jacaré, and Verde; cluster 4-Lakes Gambá and Gambazinho, and cluster 5-Lake Amarela. Geographic distance between lakes did not correlate significantly with interlake similarity in phytoplankton composition $(\mathrm{r}=0.03 ; \mathrm{p}>0.05)$.

With the exception of a few pairs of lakes that are geographically proximal and were all included in the same cluster-Gambá and Gambazinho (500 m apart); Ferrugem and Ferruginha (1200 m apart); and Águas Claras and Palmeirinha (1500 m apart)-it should be noted that the clusters were composed of lakes that were distant from one another, some located within the Rio Doce State Park and others located in the surrounding areas. In addition, the difference between the gamma diversity and the mean alpha diversity, considered here as an estimate of beta diversity, was high: 347 species. This suggests that the phytoplankton species composition of such lakes is more dependent on local factors than on regional factors.
Considering that diversity and rarity are important criteria for assessing the conservation value of a given region (Coesel 2001), the possibility of protecting the middle Rio Doce lake system as a whole should be considered. That will require specific strategies for the environments surrounding the state park, with the primary objective of maintaining phytoplankton diversity at the regional level.

\section{Acknowledgments}

This study received financial support from the Conselho Nacional de Desenvolvimento Científico e Tecnológico/ Ministério da Ciência e Tecnologia (MCT/CNPq, Ministry of Science and Technology/National Council for Scientific and Technological Development), as part of the funding of the Brazilian Long-Term Ecological Research (LTER) program, Site 4 (Grant no. 520031/98-9), and from the Fundação de Amparo à Pesquisa do Estado de Minas Gerais (FAPEMIG, Foundation for the Support of Research in the state of Minas Gerais; doctoral scholarship to C.F.A.B.) We are grateful to Diego G. F. Pujoni and Maria Betânia G. Souza for their valuable suggestions, as well as to the staff of the Limnology Laboratory of the Instituto de Ciências Biológicas/Universidade Federal de Minas Gerais (ICB/UFMG, Life Sciences Institute/Federal University of Minas Gerais) for their contributions to the sampling and analysis.

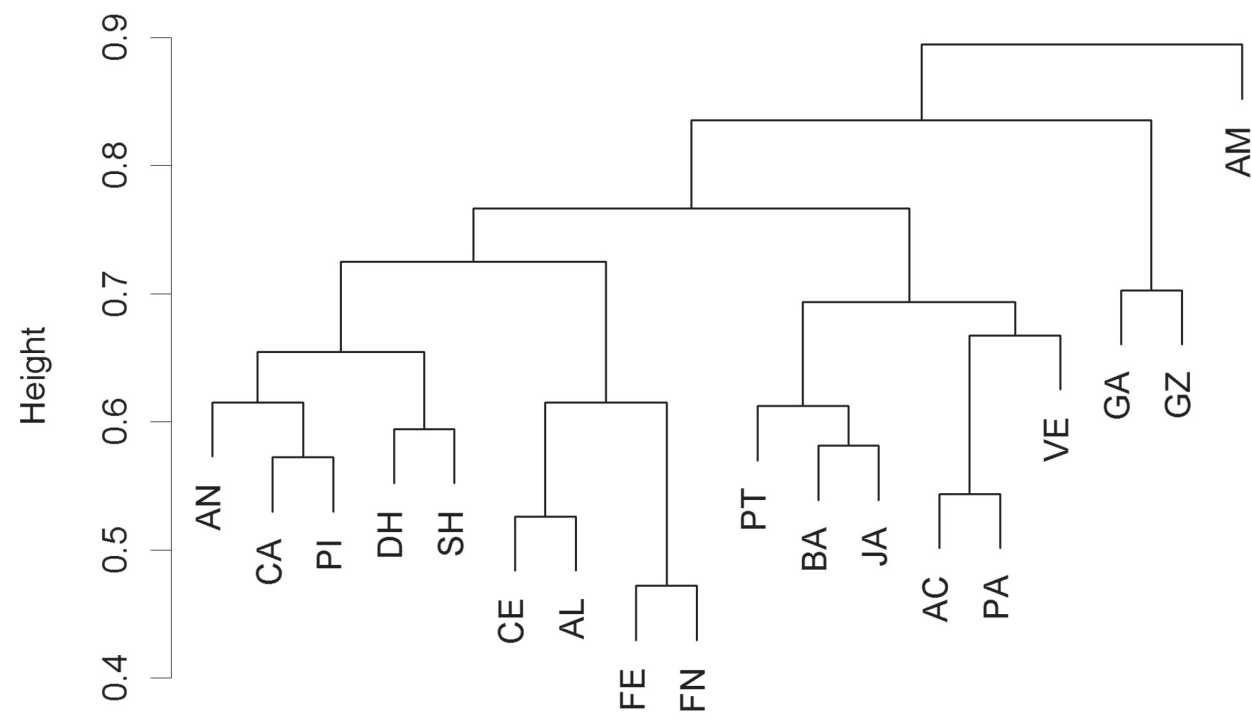

Figure 4. Cluster obtained from data of 18 lakes sampled in the middle Rio Doce lake system, between August 2007 and May 2008, considering presence and absence of species. Cluster 1-Aníbal (AN), Carioca (CA), Pimenta (PI), Dom Helvécio (DH), and Santa Helena (SH); Cluster 2-Central (CE), Almécega (AL), Ferrugem (FE), and Ferruginha (FN); Cluster 3-Águas Claras (AC), Palmeirinha (PA), Patos (PT), Barra (BA), Jacaré (JA), and Verde (VE); Cluster 4-Gambá (GA) and Gambazinho (GN); Cluster 5-Amarela (AM). 


\section{References}

Barbosa, F.A.R. \& Tundisi, J.G. 1980. Primary production of phytoplankton and environmental characteristics of a shallow quaternary lake at Eastern Brazil. Archiv fur Hydrobiologie 90(2): 139-161.

Barbosa, F.A.R.; Godinho, A.L.; Gentil, J.G. \& Pinto-Coelho, R.M. 1994. Limnologia e ictiologia. Pp. 17-23. In: Instituto Estadual de Florestas/ MG (Ed.). Anais do Workshop sobre pesquisas prioritárias para o Parque Estadual do Rio Doce. Instituto Estadual de Florestas IEF/ ENGEVIX, Belo Horizonte.

Barbosa, F.A.R. \& Padisák, J. 2002. The forgotten lake stratification pattern: atelomixis, and its ecological importance. Verhandlungen des Internationalen Verein Limnologie 28: 1385-1395.

Barros, C.F.A.; Souza, M.B.G. \& Barbosa, F.A.R. 2006. Seasonal forces driving phytoplankton size structure in a tropical deep lake (Dom Helvécio Lake, South-East Brasil). Acta Limnologica Brasiliensia 18(1): 55-66.

Bicudo, C.E.M. \& Menezes, M. 2006. Gêneros de algas de águas continentais do Brasil: Chave para Identificação e Descrições. São Carlos, Editora Rima.

Cavati, B. \& Fernandes, V.O. 2008. Algas perifíticas em dois ambientes do baixo rio Doce (lagoa Juparanã e rio Pequeno - Linhares, Estado do Espírito Santo, Brasil): variação espacial e temporal. Acta Scientiarium 30(4): 439-448.

Coesel, P.F.M. 2001. A method for quantifying conservation value in lentic freshwater habitats using desmids as indicator organisms. Biodiversity and Conservation 10(2): 177-187.

Cole, G.A. 1983. Textbook of limnology. St. Louis: The C.V. Mosby Company.

Colwell, R.K. 2006. Estimate S - Statistical estimation of species richness and shared species from samples. Version 8. University of Connecticut. Available in: http://purl.oclc.org/estimates. (Accessed 19/March/2010).

Crist, T.O.; Veech, J.A.; Gering, J.C. \& Summerville, K.S. 2003. Partitioning species diversity across landscapes and regions: a hierarchical analysis of $\alpha, \beta$, and $\gamma$ diversity. The American Naturalist 162(6):734-743.

Declerck, S.; Vandekerkhove, J.; Johansson, L.; Muylaert, K.; CondePorcuna, J.M.; Van Der Gucht, K.; Pérez-Martinéz, C.; Lauridsen, T.; Schwenk, K.; Zwart, G.; Rommens, W.; López-Ramos, J.; Jeppesen, E.; Vyverman, W.; Brendonck, L. \& De Meester, L. 2005. Multi-group biodiversity in shallow lakes along gradients of phosphorus and water plant cover. Ecology 86(7): 1905-1915.

De Meis, M.R.M. \& Tundisi, J.G. 1997. Geomorphological and limnological process as a basis for lake typology. The middle Rio Doce lake system. Pp. 25-50. In: Tundisi, J.G. \& Saijo, Y. (Ed.). Limnological Studies in the Rio Doce Valley Lakes. São Carlos, Brazilian Academy of Sciences.

Downing, A.L. \& Leibold, M.A. 2002. Ecosystem consequences of species richness and composition in pond food webs. Nature 416: 837-841.

Förster, K. 1969. Amazonische Desmidieen. 1. Areal Santarém. Amazoniana 2(1-2): 5-232.

Förster, K. 1974. Amazonische Desmidieen. 2. Areal Maués-n Abacaxis. Amazoniana 5(2): 135-242.

Hammer, O.; Harper, D.A.T. \& Ryan, P.D. 2001. Paleontological statistics software package for education and data analysis. Paleontologia electronic 4: 9 .

Henry, R. \& Barbosa, F.A.R. 1989. Thermal structure, heat content and stability of two lakes in The National Park of Rio Doce Valley (Minas Gerais, Brazil). Hydrobiologia 171(3):189-199.

Hino, K.; J.G. Tundisi \& Reynolds, C.S. 1986. Vertical distribution of phytoplankton in a stratified lake (Lago Dom Helvécio, Southeastern Brazil), with special reference to the metalimnion. Japanese Journal of Limnology 47(3): 239-246.

Komárek, J. \& K. Anagnostidis, 1989. Modern approach to the classification system of cyanophytes, 4: Nostocales. Algological Studies 82(3): 247-345.

Komárek, J. \& Anagnostidis, K. 1999. Cyanoprokaryota I. Teil Chroococcales. Pp. 1-548. In: Ettl, H.; Gärtner, G.; Heynig H. \& Mollenhauer, D. (Ed.). Süsswasserflora von Mitteleuropa 19. Verlag: G. Fischer.

Komárek, J. \& Fott, B. 1983. Chlorophyceae (Grünalgen), Ordiniung: Chlorococcales. Pp. 1-1.044. In: Huber-Pestalozzi, G.; Heynig H. \& Mollenhauer, D. (Eds.). Das phytoplankton des Sübwassers: Systematik und Biologie. Stuttgart: E. Schwiezerbat'sche Verlagsbuchlandlung.
Mackereth, F.J.H.; Heron, J. \& Talling, J.F. 1978. Water analysis. Ambleside: Scientific Publication No 36, Freshwater Biological Association.

Magurran, A.F. 2004. Measuring Biological Diversity. Oxford, Blackwell. Maia-Barbosa, P.M.; Barros, C.F.A.; Souza, M.B.G.; Faria, V.R.; Barbosa, L.G.; Brito, S.L.; Souza, R.A.; Rietzler, A.; Eskinazi-Santanna, E. \& Barbosa, F.A.R. 2006. The middle Rio Doce lakes, southeast Brazil biodiversity and its controlling forces at local and regional scales. Verhandlungen des Internationalen Verein Limnologie 29: 1-5.

Maillard, P.; Pivari, M.O. \& Luis, C.H.P. 2011. Remote Sensing for Mapping and Monitoring Wetlands and Small Lakes in Southeast Brazil. In: Chemin, Y. (Ed.). Remote Sensing of Planet Earth. Croatia, Intechweb.org.

Marques, M.M. \& Barbosa, F.A.R. 2002. Áreas prioritárias para a conservação da diversidade aquática no trecho médio da bacia do Rio Doce, MG. Naturalia 27: 211-229.

Menezes, M.; Nascimento, E.P. \& Fonseca, C.G. 1995. Flora dos Estados de Goiás e Tocantins - Criptógamos v. 4: Euglenophyceae. Goiânia, Editora UFG.

Nabout, J.C.; Nogueira, I.S.; Oliveira, L.G. \& Morais, R.R. 2007. Phytoplankton diversity (alpha, beta, and gamma) from the Araguaia River tropical floodplain lakes (central Brazil). Hydrobiologia 557: 455-461.

Nimer, E. 1989. Climatologia do Brasil. IBGE.

Nogueira, I.S., Nabout, J.C.; Oliveira, J.E. \& Silva, K.D. 2008. Diversidade (alfa, beta e gama) da comunidade fitoplanctônica de quatro lagos artificiais urbanos do município de Goiânia, GO. Hoehnea 35(2): 219-233.

Padisák, J.; Soróczki-Pintér, E. \& Reznersinking, Z. 2003. Properties of some phytoplankton shapes and the relation of form resistance to morphological diversity of plankton - an experimental study. Hydrobiologia 500: 243-257.

Prescott, G.W.; Croasdale, H.T. \& Vinard, W.C. 1975. A synopsis of North American desmids Part II. Desmidiaceae: Placodermae Section 1. USA, University of Nebraska Press.

Prescott, G.W.; Croasdale, H.T. \& Vinard, W.C. 1977. A synopsis of North American desmids Part II. Desmidiaceae: Placodermae Section 2. USA, University of Nebraska Press.

Prescott, G.W.; Croasdale, H.T.; Vinard, W.C. \& Bicudo, C.E.M. 1981. A synopsis of North American desmids Part II. Desmidiaceae: Placodermae Section 3. USA, University of Nebraska Press.

Prescott, G.W., Croasdale, H.T. \& Vinard, W.C. 1982. A synopsis of North American desmids Part II. Desmidiaceae: Placodermae Section 4 USA, University of Nebraska Press.

Ramsar. 2010. The Ramsar List of wetlands of international importance. Available in http://www.ramsar.org/pdf/sitelist_order.pdf. (Accessed 16/May/2011).

Reynolds, C.S. 1987. The response of phytoplankton communities to change lake environments. Schweizerische Zeitschrift fur Hydrologie 49(2): 220-236.

Reynolds, C.S. 1997. On the vertical distribution of phytoplankton in the middle Rio Doce valley lakes. Pp. 227-241. In: Tundisi, J.G. \& Saijo, Y. (Ed.). Limnological studies on the Rio Doce valley lakes, Brazil São Carlos, Brazilian Academy of Sciences.

Rocha O.; Tundisi, T.M. \& Tundisi, J.G. 1989. The metalimnetic layer of Lake D. Helvécio: Plankton Distribution. Japanese Journal of Limnology 50(2): 168-169.

Sant'anna, C.L. 1984. Bibliotheca Phycologica. Chlorococcales (Chlorophyceae) do Estado de São Paulo, Brasil. Germany, J.Cramer.

Souza, M.B.G.; Barros, C.F.A.; Barbosa, F.; Hajinal, E. \& Padisák, J. 2008 Role of atelomixis in phytoplankton assemblages' replacement in Dom Helvécio Lake, South-East Brazil. Hydrobiologia 607: 211-224.

Taniguchi, G.M.; Rocha, O. \& Senna, P.A.C. 2003. A comunidade fitoplanctônica de um lago tropical no sudeste do Brasil (lago Dom Helvécio, estado de Minas Gerais). Caderno de Pesquisa Série Biologia, Santa Cruz do Sul 15(1): 29-55.

Tundisi, J.G. 1997. Climate; Pp. 7-11. In: Tundisi, J.G. \& Saijo, Y. (Ed.). Limnological Studies on the Rio Doce Valley Lakes, Brazil. São Paulo: Brazilian Academy of sciences, University of São Paulo, School Engineering at S. Carlos and Center for Water Resources and Applied Ecology. 
Tundisi, J.G. \& Saijo, Y. 1997. Limnological studies in the Rio Doce valley lakes, Brazil. São Paulo, Brazilian Academy of sciences, University of São Paulo, School Engineering at S. Carlos and Center for Water Resources and Applied Ecology.

Utermöhl, H., 1958. Zur vervollkomnung der quantitativen phytoplanktonmethodik. Verhandlungen Internationale Vereinigung für Theoretische und Angewandte Limnologie 9: 1-38.
Veech, J.A.; Summerville, K.S., Crist, T.O. \& Gering, J.C. 2002. The additive partitioning of species diversity: recent revival of an old idea. Oikos 99: 3-9.

Ward, J.H. 1963. Hierarchical grouping to optimize an objective function. Journal of the American Statistical Association 58(301): 236-244.

Wetzel, R.G. 2001. Limnology: Lake and River ecosystems. 3 ed. USA, Academic Press. 
Appendix 1. List of species recorded between August 2007 and May 2008 in the 18 lakes sampled in the middle Rio Doce lake system: Águas Claras (AC), Almécega (AL), Amarela (AM), Aníbal (AN), Barra (BA), Carioca (CA), Central (CE), Dom Helvécio (DH), Ferrugem (FE), Ferruginha (FN), Gambá (GA), Gambazinho (GN), Jacaré (JA), Palmeirinha (PA), Patos (PT), Pimenta (PI), Santa Helena (SH), and Verde (VE).

\begin{tabular}{|c|c|}
\hline Taxa & Occurrence \\
\hline \multicolumn{2}{|l|}{ Bacillariophyceae } \\
\hline Aulacoseira ambigua (Grunow) Simonsen & GN; AL \\
\hline Aulacoseira granulata (Ehrenberg) Simonsen & SH; AC \\
\hline Aulacoseira sp. 1 & CE; PT; AL; FE; FN; VE \\
\hline Aulacoseira sp. 2 & $\mathrm{AL} ; \mathrm{FN}$ \\
\hline Caloneis cf. & GN \\
\hline Cyclotella sp. & All except GA, PT; FE, FN \\
\hline Encyonema sp. 1 & AN; CA; CE; PT; SH; AC; FN; PA; VE \\
\hline Encyonema sp. 2 & DH; SH; FE; JA \\
\hline Encyonema sp. 3 & GN \\
\hline Encyonema sp. 4 & JA \\
\hline Eunotia lineolata Hustedt & All except CA, GA, GN, PT \\
\hline Eunotia zygodon Ehrenberg & GA; PT \\
\hline Eunotia sp. 1 & AN; CA; GA; SH; AC; AL; PA \\
\hline Eunotia sp. 2 & $\mathrm{DH} ; \mathrm{AC}$ \\
\hline Eunotia sp. 3 & GN; AL; PA \\
\hline Eunotia sp. 4 & PT; AC; VE \\
\hline Eunotia sp. 5 & GN \\
\hline Frustulia crassinervia (Brébisson) Costa & GN; PA; VE \\
\hline Frustulia krammeri Lange-Bertalot e Metzeltin & $\mathrm{CE} ; \mathrm{GA} ; \mathrm{GN}$ \\
\hline Frustulia sp. 1 & FN \\
\hline Gomphonema gracile Ehrenberg & All except CA; GA; GN \\
\hline Gomphonema subtile Ehrenberg & PI \\
\hline Hantzschia amphioxys (Ehrenberg) Grunow & GA \\
\hline Melosira varians Agardh & $\mathrm{AL} ; \mathrm{VE}$ \\
\hline Navicula sp. & CE; DH; PT; AL; BA; FN; PA; VE \\
\hline Neidium sp. & GA; GN; BA \\
\hline Nitzschia sp. & AN \\
\hline Pinnularia viridis (Nitzsch) Ehrenberg & $\mathrm{AN} ; \mathrm{CA} ; \mathrm{CE} ; \mathrm{AC} ; \mathrm{BA}$ \\
\hline Pinnularia sp. 1 & $\mathrm{AL}$ \\
\hline Pinnularia sp. 2 & GN \\
\hline Pinnularia sp. 3 & GN \\
\hline Pinnularia sp. 4 & $\mathrm{AC}$ \\
\hline Pinnularia sp. 5 & $\mathrm{PA}$ \\
\hline Stauroneis phoenicenteron (Nitzsch) Ehrenberg & GN; AM \\
\hline Stenopterobia curvula (Wm. Smith) Krammer & All except CE; SH; AL; AM; JA \\
\hline Surirella linearis W. Smith & CA; GN; AL; VE \\
\hline Synedra acus Kützing & All except GN; VE \\
\hline Urosolenia cf. eriensis (H.L.Smith) Round \& R.M. Crawford & GA; BA \\
\hline Urosolenia cf. longiseta (Zacharias) Edlung \& Stoermer & AN; CA;CE; DH;GA;SH;AC;AL; FE; FN; PA; PI; VE \\
\hline Pennales NI 1 & GN; \\
\hline Pennales NI 2 & $\mathrm{CE} ; \mathrm{AL} ; \mathrm{FE} ; \mathrm{VE}$ \\
\hline Pennales NI 3 & BA; JA \\
\hline
\end{tabular}


Appendix 1. Continuation.

\begin{tabular}{|c|c|}
\hline Taxa & Occurrence \\
\hline \multicolumn{2}{|l|}{ Chlorophyceae } \\
\hline Ankistrodesmus densus Korsikov & $\mathrm{CE} ; \mathrm{SH} ; \mathrm{VE}$ \\
\hline Ankistrodesmus falcatus (Corda) Ralfs & FN \\
\hline Ankistrodesmus fusiformis Corda & CA;CE; DH; GA; PT;SH; AC;AL; BA; FE; JA; PI \\
\hline Ankistrodesmus gracilis (Reinsch) Korsikov & $\mathrm{AC}$ \\
\hline Ankistrodesmus spiralis (Turner) Lemmermann & PT; FN; PA; VE \\
\hline Ankistrodesmus sp. 1 & $\mathrm{SH}$ \\
\hline Ankistrodesmus sp. 2 & CA; DH; GA; PT; AC; AM; BA; FE; PA; VE \\
\hline Ankyra judayi (G.M. Smithi) Fott & CE; PT; SH; AL; AM; PI; VE \\
\hline Chlamydomonadaceae NI2 & $\mathrm{AC} ; \mathrm{PA}$ \\
\hline Coelastrum cambricum Archer & CE; GA; AL; FE; FN; PA; PI \\
\hline Coelastrum microporum Nägeli & CE; PT; AL; JA \\
\hline Coelastrum pseudomicroporum Korsikov & JA \\
\hline Coelastrum pulchrum Schmidle & CE; DH; GN; SH; AC; JA; PA; PI; VE \\
\hline Coelastrum reticulatum (P.A.Dangeard) Senn & AN; CA; CE; GN; PT; AL; FE; FN; PI; VE \\
\hline Coelastrum sphaericum Nägeli & AN; CA; CE; AC; AL; FE; JA; PA; VE \\
\hline Desmodesmus armatus var. bicaudatus (Guglielmetti) Hegewald & CA; CE; SH; AC; BA; FN; JA; PA; PI \\
\hline Desmodesmus denticulatus (Lagerheim) S.S.An, T.Friedl \& E.Hegewald & AN; AC; PA; PI \\
\hline Dimorphococcus cf. lunatus A. Braun & AC; AM \\
\hline Elakatothrix cf. biplex (Nyg.) Hindák & GN \\
\hline Elakatothrix genevensis (Reverdin) Hindák & All lakes \\
\hline Eudorina elegans Ehrenberg & DH; PT; BA; PA \\
\hline Eutetramorus planctonicus (Korsikov) Bourrely & All except AN; DH; AM \\
\hline Glaucocystis cf. nostochinearum Itzigsohn & $\mathrm{SH}$ \\
\hline Gloeomonas sp. & AN; CE; SH; VE \\
\hline Golenkinia radiata Chodat & $\mathrm{CA} ; \mathrm{AC} ; \mathrm{BA} ; \mathrm{JA} ; \mathrm{PA}$ \\
\hline Gregiochloris cf. & PI \\
\hline Kirchneriella lunaris (Kirchner) K. Möbius & All except AN; PT; SH; JA \\
\hline Kirchneriella cf. obesa (W.West) Schmidle & $\mathrm{CA} ; \mathrm{CE} ; \mathrm{AL} ; \mathrm{FN}$ \\
\hline Kirchneriella roselata Hindák & PT; SH \\
\hline Korschikoviella sp. & $\mathrm{AM}$ \\
\hline Monoraphidium contortum (Thuret) Komàrková-Legnerová & All except GA; AL; AM \\
\hline Monoraphidium sp. & All except PI; VE \\
\hline Nephrocytium agardhianum Nägeli & All except SH; PI; VE \\
\hline Nephrocytium cf. lunatum W. West & $\mathrm{AM}$ \\
\hline Pectodictyon aff. & DH \\
\hline Pediastrum duplex Meyen & CA; AC; PI \\
\hline Pediastrum sp. 1 & $\mathrm{AM}$ \\
\hline Planktonema cf. & PT; SH \\
\hline Quadrigula closterioides (Bohlin) Printz & CE; DH; PT; AL; FN; PA \\
\hline Radiococcus cf. & PT; SH; VE \\
\hline Scenedesmus acuminatus (Lagerheim) Chodat & CA; CE; SH; AC; BA; FE; FN; PI \\
\hline Scenedesmus acuminatus f. maximus Uherkovich & JA; PI \\
\hline Scenedesmus arcuatus Lemmermann & AN; CE; AC; BA; PI \\
\hline
\end{tabular}


Appendix 1. Continuation.

\begin{tabular}{|c|c|}
\hline Taxa & Occurrence \\
\hline Scenedesmus bijugus (Turpin) Kutzing & All except DH; GA; FE; PI \\
\hline Scenedesmus bijugus var. disciformis (Chodat) Leite & PT; AC; BA; FN; JA; PA; PI \\
\hline Scenedesmus acunae Comas & GN; AC; PA \\
\hline Scenedesmus quadricauda (Turpin) Brébisson & CA; GN; SH; AC; AL; FE; FN; PA; PI; VE \\
\hline Scenedesmus regularis Swir & PI \\
\hline Scenedesmus spinosus Chodat & $\mathrm{CE} ; \mathrm{AL}$ \\
\hline Selenastrum sp. 1 & GA; FN \\
\hline Sphaerocystis sp. 1 & CE; GA; PT; BA; FE \\
\hline Sphaerocystis sp. 2 & $\mathrm{AL}$ \\
\hline Stauridium privum (Printz) Hegewu & PT; AL; BA; FN; PA; PI \\
\hline Stauridium tetras (Ehrenberg) Ralfs & FN; PI \\
\hline Tetraedron caudatum (Corda) Hansgirg & All except AM \\
\hline Tetraedron incus (Teiling) G.M. Smithi & GA; PT; BA \\
\hline Tetraedron minimum (A. Braun) & AN; CA;CE;DH;GA; PT; AL;BA; FE; FN; JA;PA \\
\hline Tetrallantos lagerheimii Teiling & DH; SH; AC; FE; FN; JA; PI \\
\hline Tetranephris brasiliense Leite \& C. Bicudo & $\mathrm{CA} ; \mathrm{SH}$ \\
\hline Tetranephris cf. & $\mathrm{CA} ; \mathrm{DH}$ \\
\hline Ulothrix sp. 1 & PI \\
\hline Ulothrix sp. 2 & $\mathrm{AM}$ \\
\hline Ulothrix sp. 3 & $\mathrm{AM}$ \\
\hline Volvocales NI & SH; PI \\
\hline Chaetophorales NI & GN \\
\hline Chlorococcales NI1 & GA; FN \\
\hline Chlorococcales NI2 & GN \\
\hline Chlorococcales NI3 & JA \\
\hline Chlorococcales NI4 & $\mathrm{SH}$ \\
\hline Chlorococcales NI5 & $\mathrm{SH}$ \\
\hline \multicolumn{2}{|l|}{ Chrysophyceae } \\
\hline Dinobryon bavaricum Imhof & CA; CE; DH; GA; PT; AC; AL; AM; JA; PA; PI \\
\hline Dinobryon sertularia Ehrenberg & All except GN; PT; FE; JA \\
\hline Dinobryon sp. & $\mathrm{AC}$ \\
\hline Mallomonas cf. & PT; SH; AC; AM; BA; JA \\
\hline Pteromonas cf. & DH; PT; AM \\
\hline Synura cf. & AN \\
\hline \multicolumn{2}{|l|}{ Cryptophyceae } \\
\hline Cryptomonas brasiliensis Castro, C. Bicudo \& D. Bicudo & All except PT; AM; VE \\
\hline Cryptomonas marssonii Skuja & AN;GA;PT; AC; AL;AM; BA; FN; JA; PA;PI;VE \\
\hline Cryptomonas sp. 1 & AN; DH; AC; AL; PI \\
\hline Cryptomonas sp. 2 & CE; GA; AC; AM; FE; FN; JA; PA; VE \\
\hline Cryptomonas sp. 3 & All except SH; AC; AM; VE \\
\hline Rhodomonas sp. & AN; DH; SH; FE; FN; PI \\
\hline \multicolumn{2}{|l|}{ Cyanobacteria } \\
\hline Anabaena planctonica Brunnthaler & PT; AL; PA \\
\hline Anabaena cf. solitaria Klebahn & AN; DH; GA; PT; SH; AM; FE; JA; PA; PI \\
\hline
\end{tabular}


Appendix 1. Continuation.

\begin{tabular}{|c|c|}
\hline Taxa & Occurrence \\
\hline Anabaena sp. 1 & $\mathrm{AM}$ \\
\hline Anabaena sp. 2 & DH; SH; AC; FE; JA; PI; VE \\
\hline Anabaena sp. 3 & $\mathrm{CA} ; \mathrm{AL} ; \mathrm{BA} ; \mathrm{JA}$ \\
\hline Aphanizomenon sp. & AN \\
\hline Aphanocapsa delicatissima W. West \& G. S. West & CA; CE; GA; GN; PT; SH; AL; BA; FE; FN; JA; VE \\
\hline Aphanocapsa elachista W.West \& G.S.West & All except AM \\
\hline Aphanocapsa holsatica (Lemmermann) Cronberg \& Komárek & GA; GN; PT; JA \\
\hline \multicolumn{2}{|l|}{ Cyanobacteria } \\
\hline Aphanocapsa planctonica (G.G.Smith) Komárek et Anagnostidis & $\mathrm{CE} ; \mathrm{AL}$ \\
\hline Aphanocapsa sp. & AN; CA; CE; SH; AL; BA; FE; FN; PI; VE \\
\hline Aphanothece cf. stagnina (Sprengel) A Braun & AN; DH; SH; AL; FE; VE \\
\hline Aphanothece sp. 1 & CE; GA; GN; FN \\
\hline Aphanothece sp. 2 & $\mathrm{FE}$ \\
\hline Aphanothece sp. 3 & $\mathrm{CA} ; \mathrm{DH} ; \mathrm{SH}$ \\
\hline Aphanothece sp. 4 & JA; PA \\
\hline Asterocapsa sp. & CA; SH; JA \\
\hline Calothrix sp. & CA; DH; PT; AC; AL; AM; PA \\
\hline Chroococcus minutus (Kütz) Nägeli & All except GN; PI \\
\hline Chroococcus sp. 1 & PT; AM; JA \\
\hline Coelomorum sp. & CE; DH; SH; AC; AL; FE; FN; JA; VE \\
\hline Coelosphaerium sp. 1 & CA; CE; DH; GN; SH; AL; BA; FE; FN; JA \\
\hline Coelosphaerium sp. 2 & $\mathrm{SH}$ \\
\hline Cyanodictyon cf. iac Cronberg \& Komárek & AL; FN; VE \\
\hline Cyanodictyon imperfectum Cronberg \& Weibull & $\mathrm{CE} ; \mathrm{AL} ; \mathrm{FE} ; \mathrm{FN}$ \\
\hline Cylindrospermopsis raciborskii (Woloszynska) Seenayya \& Subba Raju & DH; PT; SH; AL; BA; FE; FN; PI; VE \\
\hline Epigloeosphaera sp. 1 & CE; DH; PT; SH; AL; FE; FN; PA \\
\hline Epigloeosphaera sp. 2 & CE; FE; FN \\
\hline Eucapsis sp. & $\mathrm{CE}$ \\
\hline Geitlerinema cf. amphibium (Agardh ex Gomont) Anagnostidis & AN; DH; SH \\
\hline Geitlerinema splendidum (Greville ex Gomont) Anagnostidis & AN; PT; AM \\
\hline Geitlerinema unigranulatum (Singh) Komárek \& Azevedo & CE; AC; JA \\
\hline Johannesbaptistia sp. & $\mathrm{AM}$ \\
\hline Leptoplyngbya sp. & $\mathrm{AC} ; \mathrm{AM}$ \\
\hline Limnothrix redekei (Van Goor) Meffert & All except AL; AM; JA; PA \\
\hline Lyngbya sp. & AN; CA; CE; DH; PT; AC; AM; BA; JA; VE \\
\hline Merismopedia glauca (Ehrenberg) Kützing & AN; CA; PT; BA; FE; FN \\
\hline Merismopedia tenuissima Lemmermann & All except AN; GN; AM; VE \\
\hline Microcrocis cf. & JA \\
\hline Microcystis aeruginosa (Kützing) Kützing & CA; CE; PT; SH; AL; BA; FE; FN; JA; PA; VE \\
\hline Microcystis novacekii (Komárek) Compère & SH; FE; JA \\
\hline Microcystis protocystis Crow & CA; CE; SH; AL; BA; FE; JA; VE \\
\hline Microcystis wesenbergii Komárek & AN; SH; AL; FN; JA \\
\hline Nostoc sp. 1 & $\mathrm{VE}$ \\
\hline Nostoc sp. 2 & SH \\
\hline
\end{tabular}


Appendix 1. Continuation.

\begin{tabular}{|c|c|}
\hline Taxa & Occurrence \\
\hline Nostoc sp. 3 & BA \\
\hline Oscillatoria sp. 1 & CA;DH; GA; PT; SH;AC; AM; BA; FN;JA;PA;PI \\
\hline Oscillatoria sp. 2 & AN; CE; AM; FE; FN; JA; PA; VE \\
\hline Planktolyngbya contorta (Lemmermann) Anagnostidis \& Komárek & CA;CE;DH;GA;GN; SH; AL; BA; FE; FN; PI; VE \\
\hline Planktolyngbya microspira Komárek et Cronberg & GN; BA \\
\hline Planktolyngbya sp. & VE \\
\hline $\begin{array}{l}\text { Planktolyngbya limnetica (Lemmermann) } \\
\text { J.Komárková-Legnerová \& G.Cronberg }\end{array}$ & All lakes \\
\hline Planktothrix sp. & $\mathrm{CA} ; \mathrm{DH} ; \mathrm{AC} ; \mathrm{AM}$ \\
\hline Porphyrosiohon cf. & DH \\
\hline Pseudanabaena catenata Lauterborn & AN; SH; BA; VE \\
\hline Pseudanabaena galeata Böcher & All except AN; AM; PA \\
\hline Pseudanabaena limnetica (Lemmermannn) Komárek & AN; CA; CE; GA; AL; BA; FE; FN; PA; PI; VE \\
\hline Pseudanabaena mucicola (Nauman \& Hubber-Pestalozzi) Bourrelly & DH; GN; FE \\
\hline Pseudanabaena sp. 1 & AN; PT; PI \\
\hline Pseudanabaena sp. 2 & SH; AC; JA; PA \\
\hline Rabdoderma cf. & FN \\
\hline Radiocystis cf. & CE; GA \\
\hline Radiocystis fernandoi Komárek \& Komárkova-Legnerová & SH; AL; FE; FN \\
\hline Raphidiopsis cf. & $\mathrm{CE}$ \\
\hline Snowella cf. & JA \\
\hline Sphaerocavum brasiliense Azevedo \& Sant’Anna & DH \\
\hline Spirulina sp. 1 & PT; PI \\
\hline Spirulina sp. 2 & PT; AM \\
\hline Synechococcus cf. & DH; AC; JA; PA \\
\hline Synechocystis cf. & $\mathrm{AL} ; \mathrm{BA} ; \mathrm{FE}$ \\
\hline Chroococcales NI 1 & $\mathrm{CE} ; \mathrm{AL}$ \\
\hline Chroococcales NI 2 & $\mathrm{CE} ; \mathrm{AL}$ \\
\hline Chroococcales NI 3 & PT; FN \\
\hline Chroococcales NI 4 & CE; FE \\
\hline Chroococcales NI 5 & $\mathrm{CE}$ \\
\hline Chroococcales NI 6 & FN \\
\hline Chroococcales NI 7 & GA \\
\hline Chroococcales NI 8 & $\mathrm{SH}$ \\
\hline Chroococcales NI 9 & PI \\
\hline Chroococcales NI 10 & $\mathrm{CA}$ \\
\hline Chroococcales NI 11 & $\mathrm{CA} ; \mathrm{AM}$ \\
\hline Chroococcales NI 12 & GA \\
\hline Chroococcales NI 13 & GA \\
\hline Chroococcales NI 14 & CE; DH; AL; FN \\
\hline Chroococcales NI 15 & AL; FE; FN \\
\hline Chroococcales NI 16 & $\mathrm{CE} ; \mathrm{AL}$ \\
\hline Nostocales NI 1 & CA; GN; AC; JA; VE \\
\hline Nostocales NI 2 & $\mathrm{VE}$ \\
\hline
\end{tabular}


Appendix 1. Continuation.

\begin{tabular}{|c|c|}
\hline Taxa & Occurrence \\
\hline Nostocales NI 3 & $\mathrm{PA}$ \\
\hline Nostocales NI 4 & $\mathrm{PA}$ \\
\hline Nostocales NI 5 & PI \\
\hline Nostocales NI 6 & $\mathrm{PA}$ \\
\hline Oscillatoriales NI 1 & $\mathrm{CE} ; \mathrm{GA}$ \\
\hline Oscillatoriales NI 2 & AN; CE; FN; PA \\
\hline Oscillatoriales NI 3 & AN \\
\hline Pseudanabaenaceae NI 1 & $\mathrm{AC}$ \\
\hline Pseudanabaenaceae NI 2 & $\mathrm{CE} ; \mathrm{PA}$ \\
\hline Pseudanabaenaceae NI 3 & $\mathrm{PT}$ \\
\hline Pseudanabaenaceae NI 4 & $\mathrm{PA}$ \\
\hline Stigonematales NI 1 & PT \\
\hline Stigonematales NI 2 & JA \\
\hline \multicolumn{2}{|l|}{ Dinophyceae } \\
\hline Gymnodynium sp. & All except AM; BA \\
\hline Peridinium baliense Lindemann & All except PT; AM \\
\hline Peridinium cf. africanum Lemmermann & AN; CA; PT; SH; AC; AL; AM; FE; FN; VE \\
\hline Peridinium cf. volzii Lemmermann & AL; AM; BA; FE \\
\hline Peridinium pusillum (Pénard) Lemmermann & All lakes \\
\hline Peridinium sp. 1 & $\mathrm{VE}$ \\
\hline Peridinium sp. 2 & $\mathrm{AN} ; \mathrm{CA} ; \mathrm{AC}$ \\
\hline Peridinium sp. 3 & $\mathrm{SH}$ \\
\hline \multicolumn{2}{|l|}{ Euglenophyceae } \\
\hline Euglena acus Ehrenberg & CE; AC; AM; PA; PI \\
\hline Euglena ehrenbergii Klebs & PT; AC; AL; AM \\
\hline Euglena oxyuris Schmarda & AN; CA; CE; AC; AM; PA \\
\hline Lepocinclis fusiformis (H.J.Carter) Lemmermann & AM; PI \\
\hline Lepocinclis cf. ovum (Ehrenberg) Lemmermann & SH \\
\hline Lepocinclis sp. 1 & CA; CE; DH; AM; PA; VE \\
\hline Lepocinclis sp. 2 & GN \\
\hline Lepocinclis sp. 3 & $\mathrm{AM}$ \\
\hline Lepocinclis sp. 4 & JA \\
\hline Monomorfina cf. pyrum (Ehrenberg) Mereschkowski & DH; SH; AC; PA \\
\hline Phacus hamatus Pochmann & AN; PT; AM; BA; FN; JA; PI \\
\hline Phacus longicauda (Ehrenberg) Dujardin & AN; JA; GN; SH; AC; AM; BA; FN; JA; PI \\
\hline Phacus onyx Pochmann & CA; CE; AM \\
\hline Phacus raciborskii Drezepolski & CA; CE; JA; GA; PT; AM; JA; PA; PI; VE \\
\hline Phacus suecicus Lemmermann & $\mathrm{AL} ; \mathrm{AM} ; \mathrm{BA}$ \\
\hline Phacus sp. 1 & $\mathrm{AM}$ \\
\hline Phacus sp. 2 & JA; SH; AC; AM \\
\hline Phacus sp. 3 & GN; FN \\
\hline Rhabdomonas sp. & GA \\
\hline Strombomonas cf. encifera & PI \\
\hline Strombomonas cf. gibberosa & $\mathrm{AM}$ \\
\hline
\end{tabular}


Appendix 1. Continuation.

\begin{tabular}{|c|c|}
\hline Taxa & Occurrence \\
\hline Trachelomonas mirabilis var. spinosa Svirenko & AM; PA; PI \\
\hline Trachelomonas armata (Ehrenberg) Stein & AN; CA; PT; AC; AM; FN; JA; PI \\
\hline Trachelomonas cf. magdaleniana Deflandre & $\mathrm{AM}$ \\
\hline Trachelomonas cf. oblonga Lemmermann & SH \\
\hline Trachelomonas cf. spinosa Stokes & JA \\
\hline Trachelomonas hispida var. coronata Lemmermann & $\mathrm{CE} ; \mathrm{AC}$ \\
\hline Trachelomonas hispida var. duplex Deflandre & SH; AM; BA; JA; PA; JA \\
\hline Trachelomonas cf. zingeri Roll & CE; JA; PA \\
\hline Trachelomonas lacustris Drezepolski & AM; JA; FN; JA; PA; JA \\
\hline Trachelomonas megalacantha Da Cunha & $\mathrm{AM}$ \\
\hline Trachelomonas volvocina Ehrenberg & All lakes \\
\hline Trachelomonas sp. 1 & SH; AL \\
\hline Trachelomonas sp. 2 & CA; CE; AC; AM; JA; FN \\
\hline Trachelomonas sp. 3 & AN; SH \\
\hline Trachelomonas sp. 4 & AC; JA; PA \\
\hline Trachelomonas sp. 5 & $\mathrm{AM}$ \\
\hline Trachelomonas sp. 6 & $\mathrm{AM}$ \\
\hline Trachelomonas sp. 7 & DH \\
\hline Euglenales NI 1 & AN; AC; AM; BA; JA; PA; JA \\
\hline Euglenales NI 2 & GA \\
\hline Euglenales NI 3 & GA \\
\hline Euglenales NI 4 & $\mathrm{CE}$ \\
\hline \multicolumn{2}{|l|}{ Oedogoniophyceae } \\
\hline Oedogonium sp. & CA; GA; GN; PT; AC; AL; AM; PA; JA \\
\hline \multicolumn{2}{|l|}{ Trebouxiophyceae } \\
\hline Actinastrum aciculare Playfair & AN; CA; GA; FE; FN; JA; PA; PI \\
\hline Actinastrum hantszchii Lagerheim & GA \\
\hline Botryococcus braunii Kützing & All lakes \\
\hline Botryococcus protuberans W.West \& G.S.West & All except DH; GA; SH; FE \\
\hline Botryococcus terribilis J. Komárek \& P. Marvan & All except GN; BA; VE \\
\hline Chlorella sp. & All except PA \\
\hline Closteriopsis sp. 1 & All except VE \\
\hline Closteriopsis sp. 2 & CA; GN; SH; AC; JA; PI; VE \\
\hline Crucigenia cf. fenestrata (Schimidle) Shimidle & $\mathrm{AL} ; \mathrm{BA} ; \mathrm{JA} ; \mathrm{VE}$ \\
\hline Crucigenia cf. quadrata Morren & $\mathrm{CE}$ \\
\hline Crucigenia tetrapedia (Kirchner) W.West \& G.S.West & All except DH; GA; GN; FE \\
\hline Crucigeniella crucifera (Wolle) Komárek & PI \\
\hline Crucigeniella retangularis (Nägeli) Komárek & AN; CA; CE; PT; AL; AM; BA; FE; JA; PA; PI \\
\hline Dictyosphaerium erenbergianum Nägeli & GN; AL; FE; JA \\
\hline Dictyosphaerium pulchellum Wood & All except DH; GA; GN; BA; VE \\
\hline Keratococcus sp. & AN; CA; CE; PT; SH; AL; BA; FN; PI \\
\hline Oocystis cf. nephrocytioides Fott \& Cado & PT; SH \\
\hline
\end{tabular}


Appendix 1. Continuation.

\begin{tabular}{|c|c|}
\hline Taxa & Occurrence \\
\hline Oocystis cf. solitaria Wittrock & AN; GA; PT; FE \\
\hline Oocystis lacustris Chodat & All except AN; CA; GA; GN \\
\hline Oocystis sp. 1 & CE; GA; AL; BA; PA; \\
\hline Oocystis sp. 2 & All except GA; GN; PI; VE \\
\hline Oocystis sp. 3 & All except AN; GN; PA \\
\hline Oocystis sp. 4 & AM; BA \\
\hline Oocystis sp. 5 & DH \\
\hline \multicolumn{2}{|l|}{ Xanthophyceae } \\
\hline Centritractus sp. & CA; PT; SH; BA; JA; JA \\
\hline Isthmochloron lobulatum (Nägeli) Skuja & AN; DH; GN; PT; AL; AM; BA; JA; JA; VE \\
\hline Isthmochlorum gracile (Reinsch) Skuja & CA; CE; SH; PA; JA \\
\hline Pseudostaurastrum sp. & AC; AM; JA \\
\hline Tetraplektron cf. bourrelyi Ettl & AN; DH; GA; AC; AM; BA; PI \\
\hline Tetraplektron torsum (Skuja) Dedus. & AC; AM; FN; JA; PA \\
\hline Tetraplektron sp. 1 & CA; CE; DH; GN; PT; SH; AC; FN; JA; PA; PI;VE \\
\hline Tetraplektron sp. 2 & AN; AM; BA; FE; FN; JA; PA \\
\hline \multicolumn{2}{|l|}{ Zygnematophyceae } \\
\hline Actinotaenium sp. & AM; JA \\
\hline Bambusina Brébissonii Kützing & $\mathrm{AC} ; \mathrm{AM}$ \\
\hline Bourrellyodesmus jolyanus C. Bicudo \& Azevedo & PT; SH; AC; JA; PA; VE \\
\hline Closterium cf. setaceum Ehrenberg & PT; AC; AM; PA; PI; VE \\
\hline Closterium closterioides (Ralfs) Louis \& Peeters & GN; AC \\
\hline Closterium dianae Ehrenberg & $\mathrm{CE}$ \\
\hline Closterium gracile Brébisson ex Ralfs & CA; AC; AM; BA; FN; PA; PI \\
\hline Closterium kuetzingii Brébisson & AN; CE; DH \\
\hline Closterium moniliferum (Bory) Ehrenberg ex Ralfs & GN \\
\hline Closterium cf. turgidum Ehrenberg & $\mathrm{AC}$ \\
\hline Closterium sp. 1 & $\mathrm{CE} ; \mathrm{AL}$ \\
\hline Closterium sp. 2 & $\mathrm{GN} ; \mathrm{AM}$ \\
\hline Closterium sp. 3 & GN; AM \\
\hline Closterium sp. 4 & PA \\
\hline Cosmarium asphaerosporum Wittrock & All except AM \\
\hline Cosmarium bioculatum Brébisson in Ralfs & AN; CA; GA; SH; AC; BA; FE; FN; JA; PA; PI \\
\hline Cosmarium conspersum Ralfs & CE; PT; FE; PI \\
\hline Cosmarium contractum Kirchner & All lakes \\
\hline \multicolumn{2}{|l|}{ Cosmarium depressum (Nageli) Lundell } \\
\hline Cosmarium lagoense Nordstedt & $\mathrm{AL} ; \mathrm{BA}$ \\
\hline Cosmarium moniliforme West \& West & All except AM; PI \\
\hline Cosmarium monomazum P.Lundell & AN; CE; DH; PT; AC; BA; FN; JA; PA; VE \\
\hline Cosmarium ornatum Ralfs & $\mathrm{JA} ; \mathrm{PA}$ \\
\hline Cosmarium portianum Archer & GN; AC; JA; PA \\
\hline Cosmarium pseudoconnatum Nordstedt & All except GA; AM \\
\hline Cosmarium cf. pseudopyramidatum Lundell & GN \\
\hline
\end{tabular}


Appendix 1. Continuation.

\begin{tabular}{|c|c|}
\hline Taxa & Occurrence \\
\hline Cosmarium pyramidatum Brébisson in Ralfs & DH; GA; AC; BA; FE; FN; PA; VE \\
\hline Cosmarium quadrum P.Lundell & CE; DH; GA; GN; AC; AL; BA; FN; JA; VE \\
\hline Cosmarium trilobulatum Reinsch & $\mathrm{PA}$ \\
\hline Cosmarium cf. zonatum P.Lundell & $\mathrm{AC}$ \\
\hline Cosmarium sp. 1 & $\mathrm{CE} ; \mathrm{AL} ; \mathrm{AM}$ \\
\hline Cosmarium sp. 2 & $\mathrm{AN} ; \mathrm{AL} ; \mathrm{PA}$ \\
\hline Cosmarium sp. 3 & BA; FN; PA \\
\hline Cosmarium sp. 4 & BA \\
\hline Cosmarium sp. 5 & AC; FE; FN; JA; PA; VE \\
\hline Cosmarium sp. 6 & $\mathrm{BA} ; \mathrm{VE}$ \\
\hline Cosmarium sp. 7 & VE \\
\hline Cosmarium sp. 8 & CA; GN; PA \\
\hline Cosmarium sp. 9 & $\mathrm{AM}$ \\
\hline Cosmarium sp. 10 & $\mathrm{AM}$ \\
\hline Cosmarium sp. 11 & AC; AM; PA \\
\hline Cosmarium sp. 12 & $\mathrm{AM}$ \\
\hline Cosmarium sp. 13 & $\mathrm{AM}$ \\
\hline Cosmarium sp. 14 & $\mathrm{AM}$ \\
\hline Cosmarium sp. 15 & $\mathrm{PA}$ \\
\hline Cosmarium sp. 16 & $\mathrm{PA}$ \\
\hline Cosmarium sp. 17 & JA \\
\hline Desmidium aptogonum Brébisson & $\mathrm{SH} ; \mathrm{BA}$ \\
\hline Desmidium grevillei (Kützing ex Ralfs) De Bary & $\mathrm{CA}$ \\
\hline Desmidium swartzii Agardh & $\mathrm{SH}$ \\
\hline Euastrum cf. abruprum Nordstedt & GN; PT; FN \\
\hline Euastrum didelta (Turpin) Ralfs & GN \\
\hline Euastrum elegans (Brébisson) Kützing & $\mathrm{AM}$ \\
\hline Euastrum pulchellum Brébisson & PT; BA \\
\hline Gonatozygon Brébissonii De Bary & AM; BA; PI \\
\hline Gonatozygon cf. pillosum Wolle & GA; PT \\
\hline Gonatozygon monotaenium De Bary in West \& G.S.West & GN; BA \\
\hline Haplotaenium minutum (Ralfs) Delponte & DH; AC; PI; VE \\
\hline Hyaloteca sp. & PT; AC; AL; JA; PA; VE \\
\hline Micrasterias abrupta West \& G.S.West & $\mathrm{AC} ; \mathrm{PA}$ \\
\hline Micrasterias arcuata Bailey & $\mathrm{AC}$ \\
\hline Micrasterias borgei $\mathrm{H}$. Krieger & GN \\
\hline Micrasterias crux-melitensis (Ehrenberg) Ralfs & FN; VE \\
\hline Micrasterias oscitans var. mucronata (R.V.Dixon) J.N.F.Wille & $\mathrm{AC} ; \mathrm{PA}$ \\
\hline Micrasterias pinnatifida (Kützing) Ralfs & AC; AL; JA; PA \\
\hline Micrasterias tropica Nordstedt & $\mathrm{AM}$ \\
\hline Micrasterias truncata (Corda) Bréb. ex Ralfs & AN; DH; AC; AL; AM; JA; JA; PA; PI; VE \\
\hline Mougeotia sp. 1 & AN; GN; PT; AC; AM \\
\hline Mougeotia sp. 2 & $\mathrm{AM}$ \\
\hline
\end{tabular}


Appendix 1. Continuation.

\begin{tabular}{|c|c|}
\hline Taxa & Occurrence \\
\hline Netrium sp. & $\mathrm{PA}$ \\
\hline Octacanthium mucronulatum (Nordstedt) P.Compère & CA; PA; PI; VE \\
\hline Octacanthium sp. & $\mathrm{JA}$ \\
\hline Onychonema laeve Nordstedt & PT \\
\hline Pleurotaenium cf. baculoides (Skuja) Krieger & $\mathrm{AC}$ \\
\hline Pleurotaenium sp. & AM; PA; VE \\
\hline Sirogonium cf. & $\mathrm{AM}$ \\
\hline Sphaerozosma sp. & CE; DH; SH; FE; FN; JA; PA; PI \\
\hline Spirogyra sp. 1 & AN \\
\hline Spirogyra sp. 2 & $\mathrm{VE}$ \\
\hline Spirogyra sp. 3 & $\mathrm{AM}$ \\
\hline Spondylosium panduriforme (Heimerl) Teiling & AN; CE; DH; PT; SH; AL; AM; BA; JA; PA; VE \\
\hline Spondylosium planum (Wolle) West \& G.S.West & $\mathrm{JA}$ \\
\hline Staurastrum avicula Brébisson & All except PT; SH; BA \\
\hline Staurastrum brasiliense Nordstedt & PT \\
\hline Staurastrum cerastes Lundell & AN; DH; PT; AL; BA; FN; PA; PI; VE \\
\hline Staurastrum chaetoceras (Schröder) G.M.Smith & AN; CA; CE; DH; GA; GN; PT; SH; FN; PA; PI \\
\hline Staurastrum curvimarginatum Scott et Grönblad & $\mathrm{PA}$ \\
\hline Staurastrum depressiceps Scott et Grönblad & CE; BA; FE; JA; PA \\
\hline Staurastrum forficulatum Lundell & All lakes \\
\hline Staurastrum gemelliparum Nordstedt & $\mathrm{CA} ; \mathrm{FN}$ \\
\hline Staurastrum grallatorium Nordstedt & GA; PT; AC; AL; BA; JA; PA; VE \\
\hline Staurastrum ionatum Wolle & All except AM; FE \\
\hline Staurastrum cf. hagmannii Grönblad & PT; BA; PA \\
\hline Staurastrum cf. hirsutum Borge & $\mathrm{DH} ; \mathrm{SH}$ \\
\hline Staurastrum laeve Ralfs & All except GN; AM \\
\hline Staurastrum leptacanthum Nordstedt & CA; PT; AC; BA; FE; JA; VE \\
\hline Staurastrum leptocladum Nordstedt & All lakes \\
\hline Staurastrum manfeldtii Delponte & PT; SH; AC; AL; FN; JA; PA; PI; VE \\
\hline Staurastrum minnesotense Wolle & AN; PT; FE; FN; JA \\
\hline Staurastrum cf. muticum (Brébisson) Ralfs & AN; CE; GA; GN; PT; AC; FE; FN; PA; PI \\
\hline Staurastrum nudibrachiatum Borge & PT; AL; BA; JA; VE \\
\hline Staurastrum orbiculare (Ehrenberg) Ralfs & CA; AM; PI \\
\hline Staurastrum quadrangulare Brébisson & AC; BA; PI \\
\hline Staurastrum rotula Nordstedt & All lakes \\
\hline Staurastrum sebaldii Reinsch & SH; PI \\
\hline Staurastrum setigerum Gleve & All except CA; CE; AM; PA; PI \\
\hline Staurastrum sexangulare Bulnheim (Rabenhorst) & PT \\
\hline Staurastrum smithii (G.M. Smith) Teiling & All except GN; AM; VE \\
\hline Staurastrum taylorii Grönblad & CA; DH; AC; AM; JA; PA; VE \\
\hline Staurastrum teliferum Ralfs & $\mathrm{AN} ; \mathrm{CE} ; \mathrm{DH} ; \mathrm{AC}$ \\
\hline Staurastrum teliferum Ralfs var. 2 & PT; SH; AC; FE; FN; PA; VE \\
\hline
\end{tabular}


Appendix 1. Continuation.

\begin{tabular}{|c|c|}
\hline Taxa & Occurrence \\
\hline Staurastrum tentaculiferum Borge & AC; PA; VE \\
\hline Staurastrum tetracerum (Kützing) Ralfs ex Ralfs & AN;CA; DH; SH; AC; BA;FE;FN; JA; PA; PI;VE \\
\hline Staurastrum trifidum Nordstedt & All except SH; AM \\
\hline Staurastrum wolleanum Butler cited in Wolle & AN; PT; AL; PA; VE \\
\hline Staurastrum sp. 1 & All except DH; AM \\
\hline Staurastrum sp. 2 & AN; CE; DH; GA; AC; AL; FE; JA; VE \\
\hline Staurastrum sp. 3 & $\mathrm{CE} ; \mathrm{AC} ; \mathrm{AL} ; \mathrm{AM} ; \mathrm{VE}$ \\
\hline Staurastrum sp. 4 & GN; AL; FE; FN; VE \\
\hline Staurastrum sp. 5 & CE; PT; BA; JA; PA \\
\hline Staurastrum sp. 6 & FN \\
\hline Staurastrum sp. 7 & CA; PT; JA; PA; PI \\
\hline Staurastrum sp. 8 & DH; SH; BA; PA; PI \\
\hline Staurastrum sp. 9 & BA \\
\hline Staurastrum sp. 10 & DH; SH; AC; BA; JA; PA; PI; VE \\
\hline Staurastrum sp. 11 & GA; PT; SH; AC; AM; BA; JA; PA \\
\hline Staurastrum sp. 12 & SH; JA \\
\hline Staurastrum sp. 13 & PI \\
\hline Staurastrum sp. 14 & VE \\
\hline Staurastrum sp. 15 & $\mathrm{AM}$ \\
\hline Staurastrum sp. 16 & AN; CE; FE; FN; JA \\
\hline Staurastrum sp. 17 & PA \\
\hline Staurastrum sp. 18 & $\mathrm{AC}$ \\
\hline Staurastrum sp. 19 & $\mathrm{AC}$ \\
\hline Staurastrum sp. 20 & AC; JA \\
\hline Staurastrum sp. 21 & $\mathrm{AC}$ \\
\hline Staurastrum sp. 22 & GA; FE; FN \\
\hline Staurodesmus convergens (Ehrenberg Ex Rafs) Teiling & All except GN; PT; AM; JA; VE \\
\hline Staurodesmus convergens (Ehrenberg Ex Rafs) Teiling var. 2 & AC; BA; FN; JA; PI \\
\hline Staurodesmus crassus (West \& West) Florin & All except GN; AM \\
\hline Staurodesmus cuspidatus (Brébisson) Teiling & All except GA; AC; AL; AM; VE \\
\hline Staurodesmus dejectus (Brébisson) Teiling & All lakes \\
\hline Staurodesmus cf. extensus (Anderson) Teiling & AC; PA \\
\hline Staurodesmus incus (Brébisson) Teiling & CA; CE; FE; PI \\
\hline Staurodesmus jaculiferus (W. West) Teiling & All except SH; AM \\
\hline Staurodesmus lobatus (Borgesen) Bourrely & AC; AM; BA; FN; JA; PI; VE \\
\hline Staurodesmus o’mearii (Archer) Teiling & CA; CE; DH; GA; FN; VE \\
\hline Staurodesmus pachyrhynchus (Nordst.) Teiling & $\mathrm{AL} ; \mathrm{BA} ; \mathrm{FN}$ \\
\hline Staurodesmus phimus (Turner) Thomasson & CE; PI; VE \\
\hline Staurodesmus subulatus (Kützing) Croasdale & AN;CA;DH; GN;AL;AM; BA; FE; FN; JA; PA;PI \\
\hline Staurodesmus sp. 1 & DH; AC; AL; FE; FN; JA; PA; VE \\
\hline Staurodesmus sp. 2 & GA; AC; FN; PA; VE \\
\hline Staurodesmus sp. 3 & AN; CE; PT; AL \\
\hline Staurodesmus sp. 4 & FE; PA \\
\hline
\end{tabular}


Appendix 1. Continuation.

\begin{tabular}{lc}
\hline Taxa & Occurrence \\
\hline Staurodesmus sp. 5 & AN; AL \\
Staurodesmus sp. 6 & JA \\
Staurodesmus sp. 7 & AN; VE \\
Staurodesmus sp. 8 & FN; JA; PA \\
Staurodesmus sp. 9 & PT; PI \\
Staurodesmus sp. 10 & CA; VE \\
Staurodesmus sp. 11 & VE \\
Staurodesmus sp. 12 & AM \\
Staurodesmus sp. 13 & AM; PI \\
Staurodesmus sp. 14 & JA \\
Staurodesmus sp. 15 & AC \\
Teilingia granulata (J.Roy \& Bisset) Bourrelly & All except AM \\
Teilingia sp. 1 & GA \\
Teilingia sp. 2 & GN; AL; VE \\
Triploceras gracile Bailey & JA; PA \\
Xanthidium regulare Nordstedt & PA \\
Zygnema aff. & GN \\
\hline
\end{tabular}

